\title{
Malignant Transformation of Exophytic Sinonasal Papilloma: Case Report
}

\author{
István Magyarosi*1, J Cifra ${ }^{2}$, I Takács ${ }^{3}$, K Somogyvári ${ }^{4}$ and P Móricz ${ }^{1}$ \\ ${ }^{1}$ Department of Otorhinolaryngology, János Balassa County Hospital, Hungary \\ ${ }^{2}$ Department of Pathology, János Balassa County Hospital, Szekszárd, Hungary \\ ${ }^{3}$ University of Pécs Medical School, Department of Surgical Research and Techniques, Hungary \\ ${ }^{4}$ University of Pécs Medical School, Department of Otorhinolaryngology and Head- and Neck Surgery
}

Received: 制: December 04, 2018; Published: 制: December 12, 2018

*Corresponding author: István Magyarosi, Department of Otorhinolaryngology, János Balassa County Hospital, Hungary, Europe

\begin{abstract}
Malignant transformation of exophytic sinonasal papilloma (SP) is exceptionally rare. The authors present a case of a 48 years old woman who presented to hospital with unilateral nasal obstruction, a tissue mass in the right nasal entrance. After CT scans of the paranasal sinuses endoscopic surgery was carried out, and the lesion was removed. The histological examination discovered an exophytic SP with a part of squamosus cell carcinoma. The patient underwent radiotherapy. After that the thickened mucosa from the right sinus maxillaries was removed. Histological examination revealed SP fragments in the polypoid mucosa without any sign of malignancy. To date we have found no sign of recurrent papilloma or carcinoma. The pathogenesis of papillomas is not clear. In one third of sinonasal papillomas HPV-6 and 11 are present. In our patient no HPV DNA was identified in the removed tissues. The carcinoma and the dysplastic area was p16 positive, while the exophytic SP epithelium was negative.
\end{abstract}

\section{Introduction}

Schneiderian papillomas (SPs) of the nose (also known as sinonasal papillomas) were described by Ward in 1854. In 1991, the World Health Organization classified sinonasal papillomas into three distinct histopathological subtypes: exophytic, inverted, and oncocytic. The incidence of sinonasal papillomas is approximately 2.3 cases per 100,000 population per year. The inverted and the exophytic types are more common than the oncocytic. Malignant transformation of SP is estimated in the literature from 2 to $27 \%$ and appears mostly in inverted papillomas [1]. Malignant transformation of exophytic SP is exceptionally rare.

\section{Case Report}

A 48-year-old woman presented to the hospital with nasal obstruction. She had noticed this problem first time 27 years before. During the last months a tissue mass appeared in the nasal entrance, which deformed the right alar part of the nose. Nasal endoscopy and CT scan of paranasal sinuses showed a polyplike soft tissue mass, that filled the right sinus maxillaris, destructed its medial wall and the right ethmoid cells (Figure 1). This tissue enlargement posteriorly reached the epipharynx and anteriorly bulged into the left common nasal cavity through a septal defect. Endoscopic surgery was performed in general anesthesia. The lesion was removed in multiple parts. The tissue samples from the right nasal cavity and from the right sinus maxillaris have shown the structure of a typical exophytic Schneiderian papilloma with a part of invasive high grade planocellular carcinoma (Figure 2). Histologically exophytic proliferations with a fibrovascular core covered by transitional type epithelium could be seen, in some locations squamosus metaplasia and koilocytosis were present. The malignant transformation represented a proportion of 10$15 \%$ of the sample. At the margins of the malignant transformed area extensive features of dysplasia in the whole thickness of the epithelium was found, which represented the in situ component of the tumor.

In the invasive area there were nests of dysplastic squamosus cells, without any sign of keratinization. The tumor did not show desmoplastic reaction, but this area showed a rich inflammatory infiltrate. In the normal SP area Ki67 proliferating ratio was 
low, while at the base of the epithelium, in the in situ and the invasive areas the proliferation activity was much more elevated in the full thickness of the epithelial component. The tumor and the dysplastic area was p16 positive while the non-malignant epithelium was negative. We subjected the removed tissue sample to HPV DNA analysis using PCR. Although koilocytes were present on histological examination, no HPV DNA was found in this case. Gynecological examination has found no papilloma-like lesion and HPV detection from cervical excretion was also negative. The classification of the tumor in the TNM system was T1N0M0. The postoperative CT scan showed mucosal thickness inside the right maxillary sinus without bone destruction. The radicality of the removal could not be defined from the tissue specimen because of its fragmentation, therefore postoperative radiotherapy was given to the patient.

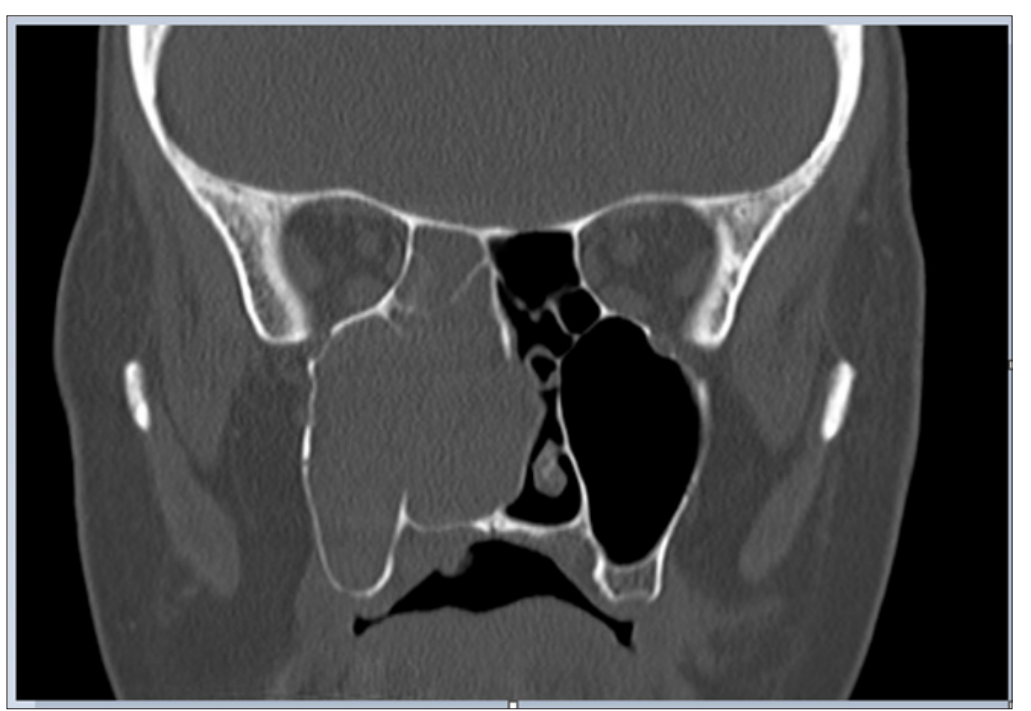

Figure 1: CT scan of paranasal sinuses shows a soft tissue mass, that fills the right sinus maxillaris, destructs its medial wall and the right ethmoid cells.

On the postoperative MRI scans mucosal thickness could be observed in the right sinus maxillaris. The thickened mucosa from the right sinus maxillaris was removed in multiple parts. Histological examination found SP fragments in the polypoid mucosa without any sign of malignancy. The patient underwent follow-up examination monthly. Due to the missing part of the medial right sinus maxillaris wall we could check endoscopically the whole right sinus maxillaris and operating field. To date we have not found any sign of recurrent papilloma or carcinoma.

\section{Discussion}

Nasal obstruction is the most common symptom of SP, followed by epistaxis, pain and asymptomaticy[2]. Exophytic papillomas almost exclusively arise from the nasal septum with rare cases arising from the lateral nasal wall [3]. The most common localisation is the transitional zone between the squamosus epithelium and the respiratory type epithelium [4]. Glatre et al. described the unifocal and the multifocal form of exophitic SPs [4]. He suggested that the multifocal form, named also florid nasal papillomatosis, has a higher recurrence than the unifocal form. These lesions are usually unilateral, the bilateral location is uncommon. In larger series, papillomas are bilateral in about $8 \%$ of cases [5]. In our case the extremely enlarged laesion was unifocal, with its origin from nearby the natural orificium of the right maxillary sinus. Patients with the exophytic subtype are usually younger, presenting in their fourth decade of life and the remaining two subtypes were more likely to occur in older patients [3]. Male predominance can be observed by exophytic and inverted papillomas, whereas the oncocytic SP has shown no sex predilection $[2,3,6]$.

Nasal trauma is present in the history of many patients with exophytic papilloma[4]. In our case nasal trauma was also present. In childhood she suffered a nasal injury. Few years later nasal aesthetic surgery was done. The macroscopic appearance of exophytic papilloma is: grey-tan, exophytic, "mushroom-shaped" verrucous papillary proliferations (Figure 3). Until radiological signs of inverted papilloma was described, there had been no specific radiological sign for exophitic sinonasal papilloma $[4,6]$. On the preoperative CT slices bone destruction can be seen (Figure 1). Bone erosion can occur without malignant transformation, but is more likely when it is present.The pathogenesis of papillomas is not clarified. Some evidence suggested that SP may be associated with HPV infection, in particular HPV 6 and 11 and sometimes 16 and $18[4,5,7]$. It is not known how HPV is transmitted to the sinonasal tract, although sexual transmission is suspected. Exophytic papillomas frequently contain low risk HPV DNA, but rarely high-risk HPV $[3,5]$. In the literature HPV 6 and 11 are mostly associated with exophytic papillomas [3,5]. In one third of sinonasal papillomas HPV 6 and 11 are present [6]. In our case no HPV DNA was identified in the removed tissues. In the international literature we found 6 cases of exophytic SP with malignant transformation. These cases are presented in a table for better comparability Table 1 [7-10]. 


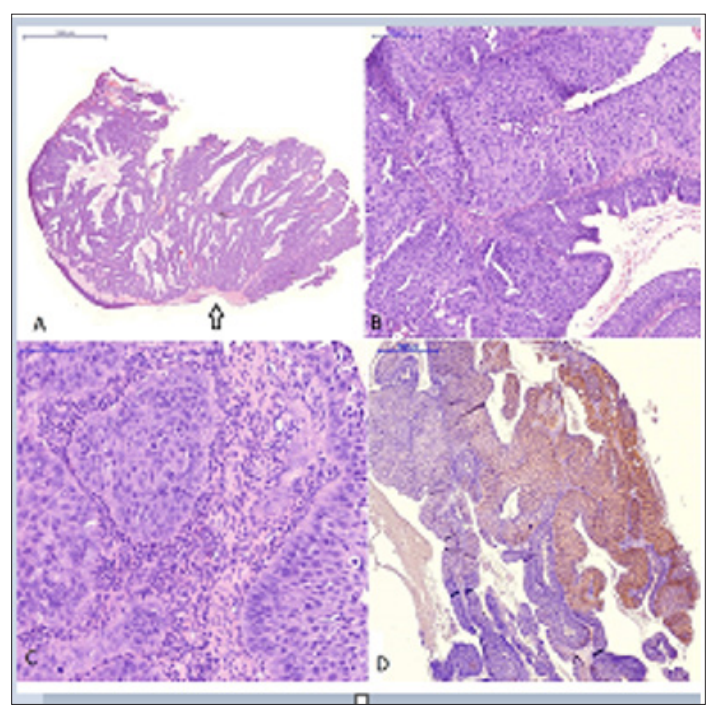

Figure 2: Histopathological findings. A) Exophytic SP, the arrow points to the peduncle.B) Dysplastic area, the in situ component of the tumor. C) Nests of invasive carcinoma. D) P16 immunhistochemical reaction.

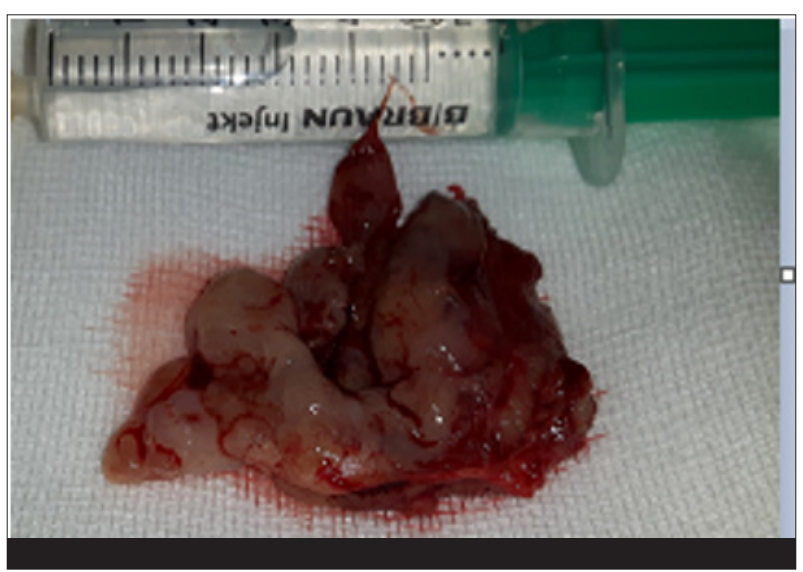

Figure 3: The removed polypoid specimen from the right nasal cavity.

Table 1: Cases of exophytic SP with malignant transformation found in international literature and our case (FESS: functional endoscopic sinus surgery; SCC: squamous cell carcinoma).

\begin{tabular}{|c|c|c|c|c|c|c|c|c|}
\hline Reported by & Age,sex & Hystory & Localisation & Symptoms & Size & $\begin{array}{c}\text { Diagnosis, } \\
\text { HPV }\end{array}$ & Treatment & $\begin{array}{l}\text { Outcome } \\
\text { (during the re- } \\
\text { ported period) }\end{array}$ \\
\hline $\begin{array}{l}\text { Nudell [1] } \\
\text { (case Nr. 7) }\end{array}$ & $\begin{array}{l}50 \text { years, } \\
\text { female }\end{array}$ & & $\begin{array}{l}\text { left nasal cavity, } \\
\text { septum }\end{array}$ & $\begin{array}{l}8 \text { months, } \\
\text { mass, occa- } \\
\text { sional sore } \\
\text { throat and } \\
\text { hoarseness }\end{array}$ & $3 \mathrm{~cm}$ & $\begin{array}{c}\text { SCC, HPV } \\
\text { negative }\end{array}$ & FESS, radiation & $\begin{array}{c}\text { no recidiva }(1,9 \\
\text { year })\end{array}$ \\
\hline $\begin{array}{c}\text { Nudell [1] } \\
\text { (case Nr. 10) }\end{array}$ & 54 years, male & & $\begin{array}{l}\text { right nasal cavi- } \\
\text { ty, septum }\end{array}$ & $\begin{array}{l}6 \text { months, } \\
\text { obstruction }\end{array}$ & $3 \mathrm{~cm}$ & $\begin{array}{l}\text { SCC, HPV } \\
\text { positive }\end{array}$ & FESS & $\begin{array}{l}\text { incomplet exci- } \\
\text { sion with local } \\
\text { desease (1 year) }\end{array}$ \\
\hline $\begin{array}{c}\text { Nudell [1] } \\
\text { (case Nr. 19) }\end{array}$ & 50 years, male & 6 years & $\begin{array}{l}\text { bilateral, nasal } \\
\text { cavity }\end{array}$ & polyps & $2,7 \mathrm{~cm}$ & $\begin{array}{c}\text { mucoepider- } \\
\text { moid carci- } \\
\text { noma, HPV } \\
\text { negative }\end{array}$ & $\begin{array}{l}\text { wide resection, } \\
\text { radiation }\end{array}$ & $\begin{array}{c}\text { no recidiva }(1,2 \\
\text { year })\end{array}$ \\
\hline $\begin{array}{c}\text { Norris [8] } \\
\text { (case Nr. 20) }\end{array}$ & 62 years, male & $\begin{array}{l}4 \text { previous } \\
\text { removals }\end{array}$ & $\begin{array}{l}\text { left nasal cavity, } \\
\text { septum, floor } \\
\text { and inferior } \\
\text { turbinate }\end{array}$ & obstruction & no data & SCC & $\begin{array}{c}\text { wide resection, } \\
\text { radiotherapy }\end{array}$ & $\begin{array}{l}\text { no recidiva (2 } \\
\text { years) }\end{array}$ \\
\hline
\end{tabular}




\begin{tabular}{|c|c|c|c|c|c|c|c|c|}
\hline Buchwald [9] & 41 years, male & $\begin{array}{c}\text { papilloma } \\
\text { removal } \\
16 \text { years } \\
\text { before }\end{array}$ & $\begin{array}{c}\text { right nasal sep- } \\
\text { tum and roof }\end{array}$ & $\begin{array}{c}\text { tissue mass by } \\
\text { self-inspection }\end{array}$ & no data & $\begin{array}{c}\text { SCC, HPV } \\
\text { positive (type } \\
6 / 11)\end{array}$ & $\begin{array}{c}\text { alar rhinotomy, } \\
\text { wide excision, } \\
\text { radiotherapy }\end{array}$ & $\begin{array}{c}\text { no recidiva (1,5 } \\
\text { year) }\end{array}$ \\
\hline Terada [10] & 58 years, male & 3 years & $\begin{array}{c}\text { right nasal } \\
\text { cavity }\end{array}$ & obstruction & $\begin{array}{c}2,5 \times 0,8 \times 0, \\
8 \mathrm{~cm}\end{array}$ & $\begin{array}{c}\text { SCC, HPV } \\
\text { negative }\end{array}$ & $\begin{array}{c}\text { polypectomy } \\
\text { with negative } \\
\text { surgical margins }\end{array}$ & $\begin{array}{c}\text { no recidiva (4 } \\
\text { years) }\end{array}$ \\
\hline Our case & $\begin{array}{c}48 \text { years, } \\
\text { woman }\end{array}$ & 27 years & $\begin{array}{c}\text { right nasal } \\
\text { cavity }\end{array}$ & obstruction & $2 \times 2 \times 5 \mathrm{~cm}$ & $\begin{array}{c}\text { SCC, HPV } \\
\text { negative }\end{array}$ & $\begin{array}{c}\text { polypectomy, } \\
\text { radiotherapy }\end{array}$ & $\begin{array}{c}\text { no malignant re- } \\
\text { cidiva (6 months) }\end{array}$ \\
\hline
\end{tabular}

\section{Conclusion}

Malignant transformation of exophytic sinonasal papilloma is extremely rare. This can happen in papillomas persisting for many years. The role of papilloma virus in malignant transformation is not elucidated. Further investigations are needed.

\section{References}

1. Nudell J, Chiosea S, Thompson LDR (2014) Carcinoma Ex-Schneiderian Papilloma (Malignant Transformation): A Clinicopathologic and Immunophenotypic Study of 20 Cases Combined with a Comprehensive Review of the Literature. Head Neck Pathol 8(3): 269-286.

2. Hyams VJ (1971) Papillomas of the nasal cavity and paranasal cavities: A clinicopathological cases of 315 cases. Ann Otol Rhinol Laryngol 80: 192-206.

3. Vorasubin N, Vira D, Suh JD, Bhuta S, Wang MB, et al. (2013) Schneiderian papillomas: Comparative review of exophytic, oncocytic, and inverted. Am J Rhinol Allergy 27(4): 287-292.

4. Glatre R, Kermadec H, Alsamad IA, Badoual C, Gauthier A, et al. (2018) Exophytic sinonasal papillomas and nasal florid papillomatosis: A retrospective study 40(4): 740-746.

ISSN: 2574-1241

DOI: 10.26717/BJSTR.2018.12.002192

István Magyarosi. Biomed J Sci \& Tech Res

(c) (i) This work is licensed under Creative Commons Attribution 4.0 License

Submission Link: https://biomedres.us/submit-manuscript.php
5. Syrjänen KJ (2003) HPV infections in benign and malignant sinonasal lesions. J Clin Pathol 56(3): 174-181.

6. Leoncini G, Zanetti L (2017) The papillomas of the sinonasal tract. A comprehensive review. Pathologica 109(1): 31-34.

7. Lewis JS Jr, Westra WH, Thompson LDR, Barnes L, Cardesa A, et al. (2014)The Sinonasal Tract: Another Potential "Hot Spot" for Carcinomas with Transcriptionally-Active Human Papillomavirus 8(3): 241-249.

8. Norris HJ (1962) Papillary lesions of the nasal cavity and paranasal sinuses. Part I. Exophytic (squamous) papilloma: A study of 28 cases. Laryngoscope 72: 1797-1801.

9. Buchwald C, Franzmann MB, Jacobsen GK, Juhl BR, Lindeberg H, et al. (1997) Carcinomas occurring in papillomas of the nasal septum associated with human papilloma virus (HPV). Rhinology 35: 74-78.

10. Terada T (2012) Case Report. Malignant transformation of exophytic Schneiderian papilloma of the nasal cavity. Pathology International 62: 199-203.

$\begin{array}{ll}\text { BIOMEDICAL } & \text { Assets of Publishing with us } \\ \text { RESEARCHES } & \text { - Global archiving of articles } \\ \text { - Immediate, unrestricted online access }\end{array}$

Cite this article: István M, J Cifra, I Takács, K Somogyvári, P Móricz. Malignant Transformation of Exophytic Sinonasal Papilloma: Case Report. 